\title{
Article
}

\section{Sustainability of Domestic Sewage Sludge Disposal}

\section{Claudia Bruna Rizzardini * and Daniele Goi}

Chemistry Physics Environment Department, University of Udine, via del Cotonificio 108, 33100 Udine, Italy; E-Mail: goi@uniud.it

* Author to whom correspondence should be addressed; E-Mail: claudia.rizzardini@uniud.it; Tel.: +39-0432-558759; Fax: +39-0432-558803.

Received: 23 December 2013; in revised form: 9 April 2014 / Accepted: 14 April 2014 /

Published: 25 April 2014

\begin{abstract}
Activated sludge is now one of the most widely used biological processes for the treatment of wastewaters from medium to large populations. It produces high amounts of sewage sludge that can be managed and perceived in two main ways: as a waste it is discharged in landfill, as a fertilizer it is disposed in agriculture with direct application to soil or subjected to anaerobic digestion and composting. Other solutions, such as incineration or production of concrete, bricks and asphalt play a secondary role in terms of their degree of diffusion. The agronomical value of domestic sewage sludge is a proved question, which may be hidden by the presence of several pollutants such as heavy metals, organic compounds and pathogens. In this way, the sustainability of sewage sludge agricultural disposal requires a value judgment based on knowledge and evaluation of the level of pollution of both sewage sludge and soil. The article analyzed a typical Italian case study, a water management system of small communities, applying the criteria of evaluation of the last official document of European Union about sewage sludge land application, the "Working Document on Sludge (3rd draft, 2000)". The report brought out good sewage sludge from small wastewater treatment plants and soils quality suggesting a sustainable application.
\end{abstract}

Keywords: sustainability; wastewater; activated sludge

\section{Introduction}

Large-scale cropland application of municipal wastewater was first practiced about 150 years ago after flush toilets and sewer systems were introduced into cities in Western Europe and North America. 
Wastewater was discharged without any treatment and receiving watercourses became heavily polluted [1]. Many "sewage farms" were designated as a preferred alternative to the direct discharge of raw sewage into waterways [2]; in 1875, this "land treatment" served England and major cities in Europe and with the new century it has also started in the United States. Sewage farms played a role in decreasing pollution in the receiving streams, and also creating several environmental sanitation problems: hydraulic and pollutant land overloading caused clogging of soil pores, soil water logging, odors and contamination of food crops [1]. This procedure was gradually abandoned with the development of more effective technologies and building municipal sewage treatment systems. Land application of sewage sludge starts with the treatment of municipal wastewater and the consequent production of an end product, a solid waste, consisting in a concentrated suspension of solids high in organics and biodegradable compounds. One of the most widely used process for the treatment of wastewaters from medium to large populations that has found application in almost all of the countries of the world is the activated sludge process. It is a biological treatment which uses a mass of microorganisms to aerobically treat wastewater. It is widely accepted that the original process is attributed to the experimental work undertaken by Dr. Edward Ardern and Mr. William Lockett and carried out at the Davyhulme Sewage Works, which at that time were operated by the Manchester Corporation, with the cooperation of Dr. Fowler in 1914 [3]. The process was developed for the treatment of domestic wastewater and it has since been adapted for removing biodegradable organics from industrial wastewaters [4]. Owing to the physical-chemical processes involved in its treatment, sewage sludge tends to concentrate heavy metals and poorly biodegradable trace organic compounds, as well as potentially pathogenic organisms (viruses, bacteria, etc.) presented in wastewaters [5]. Since the late 1970 s, source control and industrial wastewater pretreatment programs were applied to limit the discharge of industrial constituents into municipal sewers resulting in a consistent reduction of trace elements in wastewater and sewage sludge. Over the past 30 years and until now, many studies were started to understand and predict the toxicity and the fate of toxic substances and pathogens in sewage sludge when they are applied to soils [1]. Results constituted a benchmark for the development of guidelines in the United States and in western European countries. For more than 20 years, the sewage sludge directive 86/278/EEC has encouraged the use of sewage sludge in agriculture, suggesting at the same time regulation of its use to prevent possible harmful effects on soil, vegetation, animals and humans. The key concept of the directive is to consider sewage sludge as a valuable resource: in fact it is rich in plant macro and micronutrients and its application can, in the long term, improve soil fertility [6]. In Europe the most pragmatic and environmentally sustainable approach to manage sludge from wastewater treatment plants is actually recycling it on agricultural land [7]. This strategy is supported by many scientific and regulatory authorities even if it is not adopted by all European countries. In fact, the public debate on the use of sludge in agriculture is well cared about in some Member States: Northern Europe Netherlands and Flanders have prevented almost all use of sewage sludge in agriculture. Other countries such as Denmark, Germany and Sweden have established new regulations believed sufficiently stricter to reduce risks, but the political discussion is open yet. Until now, in Italy, Greece and Spain this argument is not so known, perhaps due to information deficiency [8].

In Italy, land spreading manages about the $32 \%$ of the total volume of sewage sludge produced, but the regional situation is diversified: only a few Italian regions apply to soil large amounts of sewage sludge and sometimes new advanced local regulations about land spreading are applied. As a 
consequence, landfilling is used as a forced choice for sludge not in accordance with restricted limits; this way to dispose sewage sludge represents the only management strategy in several Regions. Composting and anaerobic digestion are another ways to get to a treated product for agriculture use, but these practices are second order management solutions together with incineration and the production line of concrete, asphalt and bricks.

Apart from political choices and management strategies the matter is to establish the sustainability of sewage sludge agricultural disposal evaluating the level of pollution of both sewage sludge and amended soils and the safety of its application. The last official document from the European Union about sewage sludge should be a useful instrument to get a sense about the level of pollution of sewage sludge and soils: about twenty years passed from the first and the last European regulation on sludge in agricultural use (86/278/EEC) [9]. In this final directive, only heavy metals as potential pollutants in sewage sludge were considered, even if many studies have evidenced potential health hazards associated with sludge-borne toxic organic $[10,11]$. In the meantime, several States found a high concentration of several contaminants and set out limit values of concentration (e.g., Denmark with Linear Alchil Benzen Sulfonate); as a consequence, in 2000, the European Community elaborated a draft (Working document on sewage sludge [12]) suggesting new limits for some toxic organics on the basis of precautionary principles. The European Commission is currently assessing and reviewing the sewage sludge Directive and it has launched a study to gather existing information on the environmental, economic, and social, as well as the health impacts of sewage sludge use on land [6]. As a matter of fact, agreement on regulating organic contaminants in sewage sludge is likely to emerge as one of the most controversial aspects of the consultation on the revised Sludge Directive [7].

This paper evaluates the level of pollution of sewage sludge and amended agricultural soils applying the dictates of the Third Working document on sludge. Medium-small size wastewater treatment plants are widespread in Italy and sludge is often applied in soils for agricultural use in the nearby areas. The Italian Environmental Agency controls quality and collects data on sludge but not many studies are reported about the system sludge-amended terrains. This work makes little contribution in this field, considering the particular situation of small dimension of domestic and urban plants in a not heavily industrialized area. Analysis were performed on three typical and different sludge from wastewater treatment plants of small Italian municipalities; soils receiving continuous applications of sewage sludge produced by these plants were also investigated.

\section{Experimental Section}

This case study reports data from a wastewater-sludge management organization for small communities located in the north-east of Italy: the Poiana Waterworks Ltd. manages a water-wastewater integrated system of various small municipalities and one little industrial district in an area characterized by common rural economy. The society is in charge of the whole water management, from collecting to treatment of mainly domestic and urban wastewaters, in 31 small treatment plants (from 2.500 to 6.000 inhabitant equivalents).

This study deals with sewage sludge produced by three different wastewater treatment plants (Table 1), selected according to population served and type of treated wastewaters in compliance with Directive 91/271/EEC [13]: the first plant treats typical domestic wastewaters with a 4.000 inhabitant equivalent 
(i.e.) potential; the second (5.000 i.e.) receives domestic wastewater with agro-industrial liquid waste contributes, typically milk working and little dairy production. The last plant (6.000 i.e.) collects urban wastewater including liquid wastes from a service station with car wash facilities.

Table 1. Concentration and limit values of heavy metals in sewage sludge produced in small communities ( $\left.\mathrm{mg} \mathrm{kg}^{-1} \mathrm{DM}\right)$.

\begin{tabular}{lccccccc}
\hline \multicolumn{1}{c}{ Sample } & $\mathbf{C d}$ & $\mathbf{C r}$ & $\mathbf{C u}$ & $\mathbf{N i}$ & $\mathbf{P b}$ & $\mathbf{Z n}$ & $\mathbf{H g}$ \\
\hline Domestic & $1.357 \pm 0.026$ & $39.58 \pm 2.96$ & $456.6 \pm 7.3$ & $31.21 \pm 1.13$ & $70.69 \pm 1.46$ & $1260.8 \pm 18.1$ & $0.580 \pm 0.086$ \\
\hline $\begin{array}{l}\text { Urban with } \\
\text { agro-industrial intrusions }\end{array}$ & $0.331 \pm 0.039$ & $45.10 \pm 0.29$ & $455.2 \pm 2.1$ & $21.55 \pm 0.46$ & $18.70 \pm 0.57$ & $286.3 \pm 4.7$ & $1.320 \pm 0.210$ \\
\hline $\begin{array}{l}\text { Urban with industrial } \\
\text { intrusions }\end{array}$ & $1.099 \pm 0.032$ & $57.16 \pm 1.16$ & $727.2 \pm 7.3$ & $34.09 \pm 0.94$ & $57.84 \pm 0.49$ & $510.5 \pm 3.8$ & $1.730 \pm 0.096$ \\
\hline Limit 2000 & 10 & 1000 & 1000 & 300 & 750 & 2500 & 10 \\
\hline Limit 2015 & 5 & 800 & 800 & 200 & 500 & 2000 & 5 \\
\hline Limit 2025 & 2 & 600 & 600 & 100 & 200 & 1500 & 2 \\
\hline
\end{tabular}

The paper considers the level of pollution of sewage sludge following evaluation criteria and methods of the working document on sludge. Analysis of heavy metals $(\mathrm{Cd}, \mathrm{Cr}, \mathrm{Cu}, \mathrm{Ni}, \mathrm{Pb}, \mathrm{Zn}$ and $\mathrm{Hg}$ ) and organic compounds (PCB, PCDD/F, PAH, LAS, NPE, DEHP and EOX) were performed on these three sewage sludge samples during 2009. Detailed information about methods of analysis was published in a previous article by Rizzardini et al. (2012) [6]. These data were compared with limits for agricultural use defined by the working document on sludge.

In the study several soils interested by application of these three types of sewage sludge were also considered: on the base of sludge quantities applied to each single plot in a time lapse of ten years and annual chemical analyses of sewage sludge applied, average annual quantities of heavy metals introduced into each sample was calculated; finally, data were related to limits for soil application suggested by the working document on sludge.

From a group of 24 samples drawn from the amended plots that received great inputs of sewage sludge from the selected wastewater treatment plants, three samples were chosen.

Over a period of ten years, the first plot had received $14.53 \mathrm{t} / \mathrm{ha}$, the second $8.64 \mathrm{t} / \mathrm{ha}$ and the third $12.45 \mathrm{t} / \mathrm{ha}$ of a mixture of the three sewage sludge. Sludge was applied to soil following traditional agronomic rates mixing it with first $15 \mathrm{~cm}$ top soil surface.

\section{Results and Discussion}

\subsection{Sewage Sludge Pollution}

The Working document on sludge identified two main types of sewage sludge source of pollution: heavy metals and some groups of organic compounds. For these contaminants several concentration limits were suggested, also considering future medium (2015) and long term (2025) proposed limits.

In Table 1 average concentrations of toxic metals found in the three sewage sludge analyzed are reported; it can be noted all data are widely under limits proposed by Working document on sludge.

Generally, $\mathrm{Cd}, \mathrm{Pb}$ and $\mathrm{Zn}$ should present biggest concentrations in sewage sludge from domestic wastewaters that can be a source of pollution for soils. Feces contribute $60 \%-70 \%$ of the load of $\mathrm{Cd}$, 
$\mathrm{Zn}, \mathrm{Cu}$ and $\mathrm{Ni}$ in domestic wastewater and $>20 \%$ of the input of these elements in mixed wastewater from domestic and industrial premises. The other principal sources of metals in domestic wastewater are body care products, pharmaceuticals, cleaning products and liquid wastes [14]. Based on mass flow studies, the runoff from roofs and streets contribute $50 \%-80 \%$ of $\mathrm{Cd}, \mathrm{Cu}, \mathrm{Pb}$ and $\mathrm{Zn}$ to the total mass flow in domestic sludge [15]. Data collected in this study show that all metals considered in the Working document have similar rate of presence even if at concentrations far from limits.

Nevertheless, some other peculiarities of the case study can be underlined. Sewage sludge of sample nr. 2 has metal charges lower than others, even if it was originated from urban wastewater. These results are reasonable if we consider that the plant receives and treats mainly wastewaters from an agro-industrial pole. Sample nr. 3 has the highest concentrations of $\mathrm{Cr}, \mathrm{Ni}, \mathrm{Cu}$ and $\mathrm{Hg}$ : these values seem realistic if we consider that this plant treats urban wastewaters with intrusions from a service station with car wash facilities. Cr contamination is probably due to wear of tires and road pavements, which are the two major emission sources identified; for $\mathrm{Ni}$, in general the traffic sector dominates the emissions, even if there are reports about Ni release from older concrete surfaces [16]. High load of $\mathrm{Cu}$ and $\mathrm{Hg}$ are probably justified by the fact that they are widespread contaminants: in fact, plumbing is the main source of $\mathrm{Cu}$ in hard water areas, contributing $>50 \%$ of the $\mathrm{Cu}$ load [17]. Instead $\mathrm{Hg}$ is an ubiquitous pollutants and its stock could be dominated by the use of amalgam or by its deposits in the wastewater system [18].

Besides heavy metals, the working document on sludge regulated several persistent organic pollutants (POPs): in fact, as an end product of sewage treatment, sludge accumulates many substances, especially lipophilic ones, which are present in the wastewater but not fully degraded during wastewater treatment. The spectrum of organic substances of anthropogenic origin occurring in sewage sludge is extremely wide and constantly changing [18]. Drescher-Kaden et al. [19] reported that 332 organic substances, with the potential to exert a health or environmental hazard, had been identified in German sludge and 42 of these were regularly detected in sludge [7]. Working document on sludge proposed limit values for seven main groups of POPs, taking example from past legislation of several European Member States. The groups of compounds whose regulation has been suggested are: absorbable organic halogens (AOX), polychlorinated biphenyls (PCB), dibenzo-p-dioxins and furans $(\mathrm{PCDD} / \mathrm{F})$, polycyclic aromatic hydrocarbons (PAH), di-2-(ethyl-hexyl) phthalate (DEHP), nonylphenol and nonylphenolethoxylates (NPE) and linear alkylbenzene sulfonates (LAS). In this study we quantified organic halogen pollution with extractable organic halogen (EOX) parameter instead of AOX because of its suitability to characterized complex two-phase matrices as sludge. In Table 2 results of the chemical analysis of organic contaminants were presented: it can be noted a general respect of regulation and each sewage sludge has concentrations much lower than limits. No very significant differences among samples were noted according to potentiality, origin of wastewaters and types of sludge technologies, with the exception of LAS content in sample nr. 3. The plant related to this sludge treated wastewaters from a service station with car wash facilities and LAS are anionic surfactants employed in detergents and cleaning products. EOX values follow results obtained in another study by Goi et al. [20]: although research has been conducted in areas of the same district about 4 years ago with respect to the analysis of this study, our results present the same order of magnitude. Most of the organics included in this parameter have been classified among the most dangerous pollutants in the lists of many environmental protection agencies of all over the world [20]. 
Measure of EOX content in sludge could give a good estimation of the level of harm due to the presence of halorganics in this type of waste and EOX can be used as a measure parameter for sewage sludge quality. EOX comprises contaminants as PCBs, PCDDs and PCDFs: PCBs concentrations are lower than the detection limit and it is probably due to the fact that many countries and intergovernmental organizations have now banned or severely restricted the production, use, handling, transport and disposal of these contaminants. PCDDs and PCDFs are ubiquitous pollutants not commercially produced but formed as trace amounts of undesired impurities in the manufacture of other chemicals, such as chlorinated phenols and their derivatives, chlorinated diphenyl ethers and PCBs: a variety of sources were identified, including sewage sludge [21] and garden composts [22], in which they can be formed naturally. Although PAHs are ubiquitous chemical contaminants, toxic to humans and potentially threatening chronic long-term: compared to PCDDs/PCDFs they derive from anthropogenic and natural activities. The concentrations of PAHs are really lower than those found in a conventional wastewater treatment plant (WWTP) located in northern Italy with a capacity of about 400.000 i.e., which receives mixing wastewater and presents a concentration of PAHs of about $3 \mathrm{mg} \mathrm{kg}{ }^{-1} \mathrm{DM}$ [23]. Finally, NPEs and DEHP are used in anthropogenic activities and their concentration are much lower than limit values of concentration: NPEs are used as surface active agents in cleaning products, cosmetics and hygienic products, in emulsifications of paints and pesticides and are slowly being phased-out of the market; DEHP is the most common of the phthalate esters, which are widely used industrial chemicals, serving as important additives, which produce flexibility in polyvinylchloride (PVC) resins [24].

Table 2. Concentration and limit values of organic pollutants in sewage sludge from small communities ( $\left.\mathrm{mg} \mathrm{kg}^{-1} \mathrm{DM}\right)$.

\begin{tabular}{|c|c|c|c|c|c|c|c|}
\hline Sample & $\operatorname{EOX}(\mathrm{AOX})$ & 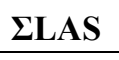 & DEHP & इNPE & ІPAH & $\Sigma P C B$ & ¿PCDD/PCDF * \\
\hline Domestic & 9.03 & 48.8 & 6.20 & 1.57 & 1.15 & $<0.0035$ & 49 \\
\hline Urban with agro-industrial intrusions & 9.79 & 64.5 & 13.04 & 1.01 & 0.55 & $<0.0035$ & 41 \\
\hline Urban with industrial intrusions & 10.10 & 239.1 & 6.31 & 0.80 & 1.03 & $<0.0035$ & 40 \\
\hline Limit 2000 & 500 & 2600 & 100 & 50 & 6 & 0.8 & 100 \\
\hline
\end{tabular}

It must be underlined that limit values for POPs were established on precautionary concentrations and were not based on ecotoxicological researches. In particular, the limit values for AOX, PCBs and $\mathrm{PCDD} / \mathrm{Fs}$ are intended as precautional and are not justified solely by toxicological implications [25]. Moreover the EU proposals include limit values for the sum of 9 PAHs, but it is not clear what criteria have been used to select these compounds. Subsequently, studies have been done to evaluate the relevance of organic micro-pollutants in sewage sludge and to suggest guide values taking into account different situations of European countries [26]. Actually, the question remains open, and the European Commission has launched a study to evaluate the presence of emerging pollutants in sewage sludge which could contaminate terrestrial and aquatic environment when sludge is used in agriculture [27].

\subsection{Soil Pollution}

Working document on sludge took in consideration also the possible contamination of soil following sewage sludge application. Because of their sparingly soluble nature and their limited uptake 
by plants, heavy metals tend to accumulate in the surface soil and become part of the soil matrix. With repeated applications of sewage sludge, heavy metals could accumulate to levels toxic to crops and build up to potentially harmful levels in humans, animals and wildlife that consume the crops [28]. In addition they can be detrimental to key microbial processes related to the cycling of nutrients and the turnover of organic matter [29]. The organic contaminants introduced into the soil through the agricultural utilization of sewage sludge are subjected to more rapid degradation, with the result that accumulations in this field can be effectively discounted [18]. It must be noticed that the presence of toxic metals in soil can severely inhibit the biodegradation of organic contaminants [30]. In our case, we focused on the study of the contribution of heavy metals on soils interested by land applications. Further, it has been calculated a parameter just considered in Sludge Directive, but often disregarded by national legislations: the average load of heavy metals added annually to soils expressed as gram of contaminant supplied per hectare and per year $\left(\mathrm{g} \mathrm{ha}^{-1} \cdot \mathrm{year}^{-1}\right)$. Considering this parameter, plots of lands interested by ten years applications of the three types of sewage sludge described above have been analyzed. Results of this study are presented in Figure 1: each soil sample is in compliance with limit values suggested by the working document on sludge, both for the actual (between 2000 and 2015) and the future period (limit 2025). Limits proposed are precautionary values for the protection of long-term soil quality having a regard to background concentrations in European agricultural soils [31]. This study highlighted some criticisms: even if in accordance with the proposals of European Commission, these results show a potential trend for future exceeding of the rate concentration limit, especially for $\mathrm{Cd}$. Secondly, the high content of $\mathrm{Cu}$ and $\mathrm{Zn}$ in sewage sludge suggests that the potential flow of these elements to soils is high with a significant accumulation. These components indicate a possible environmental impact in a longer time perspective.

These outcomes agree with and confirm the study conducted for the European Commission by Millieu/WRc/RPA, which suggests that consideration needs to be given to adjusting the maximum permissible soil metal limits in Directive 86/278/EEC for cadmium and zinc [31].

Figure 1. Effective amounts of heavy metals added annually to soils of the wastewater district and comparison with limit values suggested by the working document on sludge. (a) $\mathrm{Cd}$ and $\mathrm{Hg}$; (b) $\mathrm{Ni}$; (c) $\mathrm{Pb}$; (d) $\mathrm{Cu}$ and $\mathrm{Cr}$; (e) $\mathrm{Zn}$.

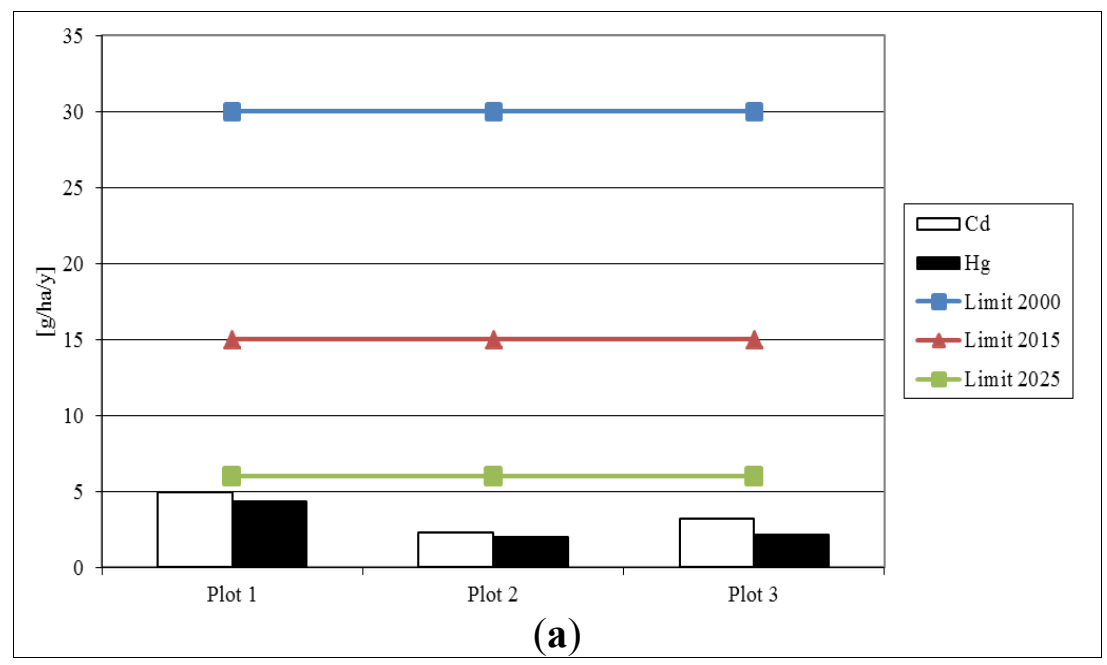


Figure 1. Cont.

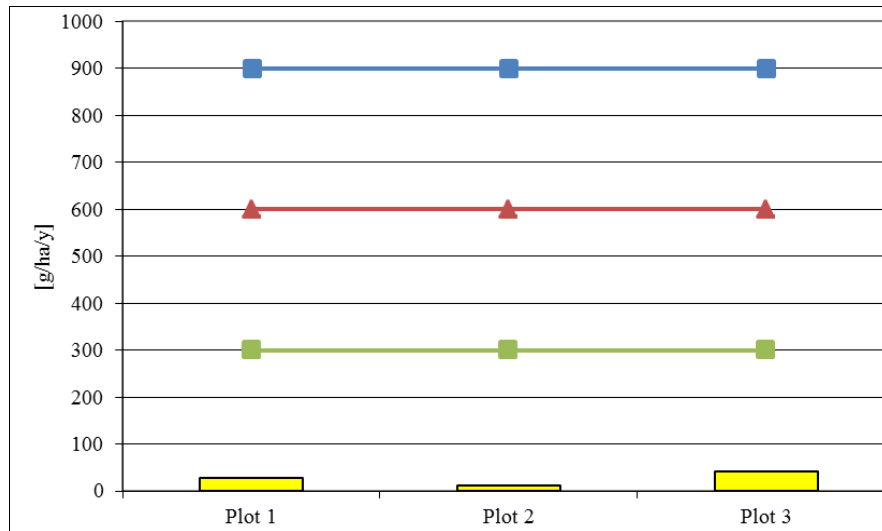

एNi

- Limit 2000

-Limit 2015

-Limit 2025

(b)

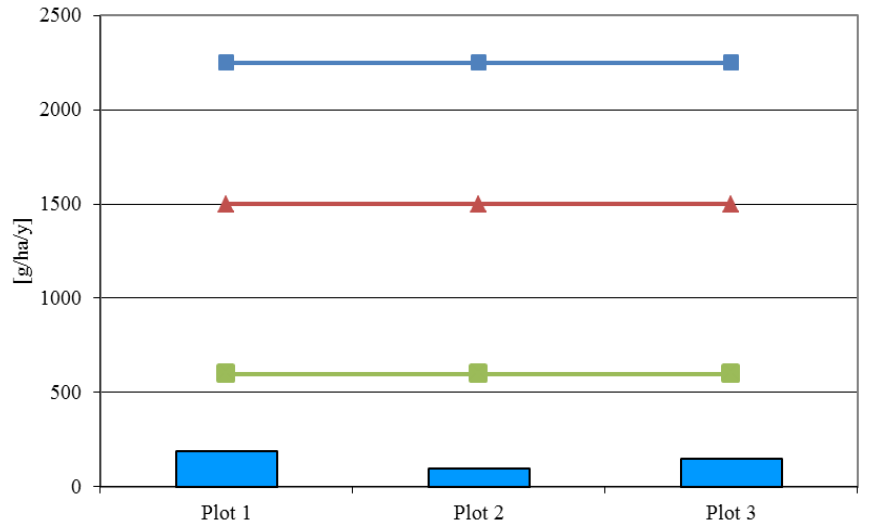

$\square \mathrm{Pb}$

-Limit 2000

$\simeq$ Limit 2015

- - Limit 2025

(c)

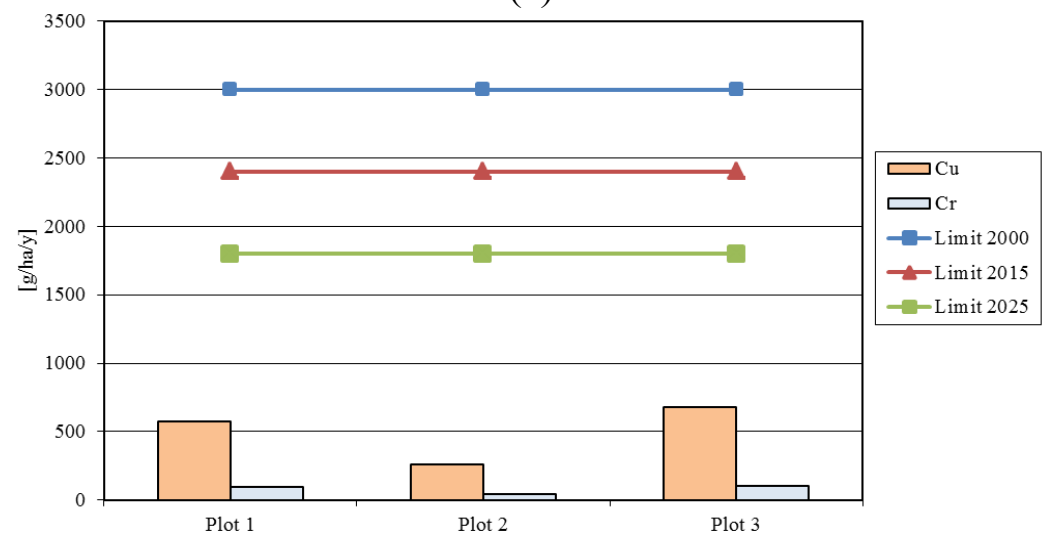

(d)

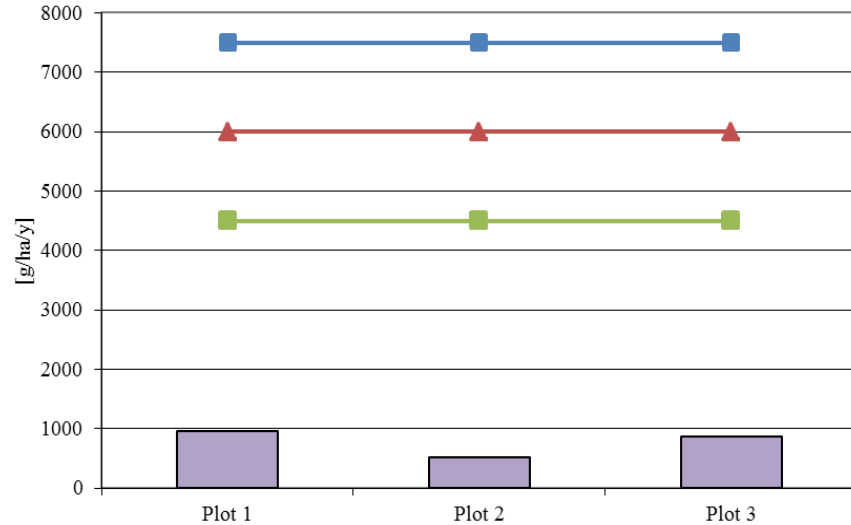

$\varpi Z n$

-Limit 2000

$\rightarrow$ Limit 2015

-Limit 2025

(e) 


\section{Conclusions}

Since sewage sludge as the main by-product of WWTP in Italy is often recycled in agriculture, it can be a guide parameter to observe regional environmental pollution from wastewater discharge. Analyses coming from this case study confirm that sewage sludge from small and medium communities have a good quality and compliance with the criteria of the Working document on sludge ensuring a safe application. However continuous and repeated applications may cause possible future heavy metals enrichment of the soil system. Data reported highlight the need for further research programs to quantify the real level of pollution of soils interested by long period land application of sewage sludge. It is also a fact that sources of heavy metals soil contamination can be found not only in sewage sludge application, but also in other agricultural practices (e.g., application of pesticides, fertilizers, animal manure). Research programs should consider and evaluate application sites ( $\mathrm{pH}$, CEC, buffering capacity, organic matter and clay content) and management of plots. The case study of Poiana Waterworks Ltd. represents a little but unique project in which the dictates of the working document on sludge are completely applied. This method should be used for valuable support in regional government regulations about sewage sludge application in agriculture following European suggestions and waiting for new directives and regulations.

\section{Acknowledgments}

The authors wish to thank the Poiana Waterworks Ltd. for technical and economic support and the Regione Friuli Venezia Giulia administration; a particular thank goes to Irene Duse and Andrea Fattori for their laboratorial support.

\section{Author Contributions}

Claudia Bruna Rizzardini has realized this work in the framework of her Ph.D. Thesis. Daniele Goi, as the scientific expert, has supervised the overall work.

\section{Conflicts of Interest}

The authors declare no conflict of interest.

\section{References and Notes}

1. Water Environment Federation. Available online: http://www.wef.org/biosolids-factsheets.aspx (accessed on 1 December 2013).

2. U.S. Environmental Protection Agency. Process Design Manual. Land Application of Municipal Sludge, 1st ed.; U.S. Environmental Protection Agency Center for Environmental Research Information: Cincinnati, OH, USA, 1983; pp. 1-5.

3. Activated Sludge: Past, Present and Future. Available online: http://www.activatedsludgeconference. com (accessed on 3 December 2013).

4. Sustarsic, M. Wastewater treatment: Understanding the activated sludge process. Chem. Eng. Prog. 2009, 105, 26-29. 
5. Jorge, F.C.; Dinis, M.A.P. Sewage sludge disposal with energy recovery: A review. ICE Proc.-Waste Res. Manag. 2012, 166, 14-28.

6. Rizzardini, C.B.; Contin, M.; de Nobili, M.; Goi, D. Sewage sludge quality from small wastewater treatment plants. ICE Proc.-Waste Res. Manag. 2012, 165, 67-78.

7. Smith, S.R. Organic contaminants in sewage sludge biosolids and their significance for agricultural recycling. Philos. Trans. R. Soc. A 2009, 367, 4005-4041.

8. European Commission. Disposal and Recycling Routes for Sewage Sludge. Part 1-Sludge Use Acceptance Report. Available online: http:/ec.europa.eu/environment/waste/sludge/pdf/ sludge_disposal1.pdf. (accessed on 14 April 2014)

9. Council Directive. Council directive on the protection of the environment, and in particular of the soil, when sewage sludge is used in agriculture. Offic. J. Eur. Comm. 1986, 181, 0006-0012.

10. O’Connor, G.A.; Haney, R.L.; Ryan, J.A. Bioavailability to plants of sludge-borne toxic organics. Rev. Environ. Contam. Toxicol. 1991, 121, 129-155.

11. Leschber, R. Part I: Evaluation of the Relevance of Organic Micro-Pollutants in Sewage Sludge. In Background Values in European Soils and Sewage Sludges; Gawlik, B.M., Bidoglio, G., Eds.; European Commission: Brussels, Belgium, 2006.

12. European Commission. Working Document on Sludge 3rd Draft; DG Environment, European Commission: Brussels, Belgium, 2000.

13. Council Directive. Council Directive 91/271/EEC of 21st May 1991 concerning urban waste water treatment. Offic. J. Eur. Comm. 1991, 135, 40-52.

14. ICON Consultants. Pollutants in Urban Waste Water and Sewage Sludge-Final Report for DG Research; Office for Official Publications of the European Communities: Luxembourg, Luxembourg, 2001.

15. Boller, M. Tracking heavy metals reveals sustainability deficits of urban drainage systems. Water Sci. Technol. 1997, 35, 77-87.

16. Persson, D.; Kucera, V. Release of metals from buildings, constructions and products during atmospheric exposure in Stockholm. Water Air Soil Pollut. 2001, 1, 133-150.

17. Bergback, B.; Johansson, K.; Mohlander, U. Urban Metal Flows-A case study of Stockholm. Review and Conclusions. Water Air Soil Pollut. 2001, 1, 3-24.

18. Schnaak, W.; Kuchler, T.; Kujawa, M.; Henschel, K.P.; Suszenbach, D. Organic contaminants in sewage sludge and their ecotoxicological significance in the agricultural utilization of sludge. Chemosphere 1997, 35, 5-11.

19. Drescher-Kaden, U.; Bruggeman, R.; Matthes, B.; Matthies, M. Contents of organic pollutants in German sewage sludges. In Effects of Organic Contaminants in Sewage Sludge on Soil Fertility, Plants and Animals; Hall, J.E., Sauerbeck, D.R., L'Hermite, P., Eds.; Commission of the European Communities: Luxembourg, Luxembourg, 1992; pp. 14-34.

20. Goi, D.; Tubaro, F.; Dolcetti, G. Analysis of metals and EOX in sludge from municipal wastewater treatment plants: A case study. Waste Manag. 2006, 26, 167-175.

21. Öberg, L.G.; Andersson, R.; Rappe, C. De Novo Formation of Hepta- and Octachlorodibenzo-p-Dioxins from Pentachlorophenol in Municipal Sewage Sludge. In Organohalogen Compounds 9; Finnish Institute of Occupational Health: Helsinki, Finland, 1992; pp. 351-354. 
22. Öberg, L.G.; Wagman, N.; Andersson, R.; Rappe, C. De Novo Formation of PCDD/Fs in Compost and Sewage Sludge-A Status Report. In Organohalogen Compounds 11; Environmental Protection Agency: Vienna, Austria, 1993; pp. 297-302.

23. Torretta, V.; Katsoyiannis, A. Occurrence of polycyclic aromatic hydrocarbons in sludges from different stages of a wastewater treatment plant in Italy. Environ. Technol. 2013, 34, 937-943.

24. Cifci, D.I.; Kinaci C.; Arikan, O.A. Occurrence of phthalates in sewage sludge from three wastewater treatment plants in Istanbul. Clean-Soil Air Water 2013, 41, 851-855.

25. Sauerbeck, D.R.; Leschber, R. Effects of Organic Contaminates in Sewage Sludge on Soil Fertility, Plants and Animals; Commission of the European Community: Luxembourg, Luxembourg, 1992; pp. 1-13.

26. Díaz-Cruz, M.S.; García-Galán, M.J.; Guerra, P.; Jelic, A.; Postigo, C.; Eljarrat, E.; Farré, M.; López de Alda, M.J.; Petrovic, M.; Barceló, D. Analysis of selected emerging contaminants in sewage sludge. Trends Anal. Chem. 2009, 28, 1263-1275.

27. Environmental Protection Branch (EPB) 296. Land Application of Municipal Sewage Sludge Guidelines; Water Security Agency: Moose Jaw, SK, Canada, 2004.

28. Obbard, J.P. Ecotoxicological assessment of heavy metals in sewage sludge amended soils. Appl. Geochem. 2001, 16, 1405-1411.

29. Maslin, P.; Maier, R.M. Rhamnolipid-enhanced mineralization of phenanthrene in organic-metal co-contaminated soils. Bioremediat. J. 2000, 4, 295-308.

30. European Commission. Working Document: Sludge and Biowaste; DG Environment, European Commission: Brussels, Belgium, 2010.

31. European Compost Network (ECN). Comments to EC DG Env. "Working Document on Sludge and Biowaste". Available online: http://circa.europa.eu/Public/irc/env/rev_sewage/library?l=/ comments_document_2010/other_stakeholders/bio-sludge-working-doc/_EN_1.0_\&a=d (accessed on 14 April 2014).

(C) 2014 by the authors; licensee MDPI, Basel, Switzerland. This article is an open access article distributed under the terms and conditions of the Creative Commons Attribution license (http://creativecommons.org/licenses/by/3.0/). 